\title{
Kontrola stemplowa umów sprzedaży nieruchomości sporządzanych przed notariuszem w świetle przepisów ustawy o opłatach stemplowych z 1926 r. - studium przypadków
}

\author{
Stamp control of real estate sale contracts drawn up before a notary public \\ in the light of the provisions of the Stamp Act of 1926 \\ Гербовый контроль договоров купли-продажи недвижимости, составленных \\ у нотариуса, в свете положений Закона о гербовом сборе от 1926 года - \\ тематическое исследование \\ SEBASTIAN KWIECIEŃ \\ Dr hab., Katolicki Uniwersytet Lubelski Jana Pawła II \\ e-mail: sebastian.kwiecien@kul.pl, https://orcid.org/0000-0003-4858-794X
}

\begin{abstract}
Streszczenie: Ustawa z 1 lipca 1926 r. o opłatach stemplowych usunęła ostatecznie z polskiego porządku prawnego przepisy państw zaborczych, eliminując rozbieżności regulacji, zawiłość legislacyjną, niejednolite ujęcie przedmiotu opodatkowania oraz archaiczne sposoby uiszczania opłaty stemplowej. Jednocześnie do 1933 r. utrzymano przepisy odrębne dla terenów b. Galicji. W konsekwencji można mówić zatem jedynie o unifikacji rodzaju pobieranych opłat stemplowych przy zachowaniu odrębnych zasad i trybu ich pobierania. Sama opłata była niczym innym jak szczególnego rodzaju świadczeniem pieniężnym pobieranym przez państwo od wszelkich pism stwierdzających czynność prawną oraz od czynności prawnych niesporządzonych w formie pisemnej. Celem ułatwienia systemu poboru opłat stemplowych ustawodawca obdarzył notariusza przymiotem organu urzędowego odpowiedzialnego za wymiar i pobór tej opłaty. Wobec takiego rozwiązania ustawodawca musiał wprowadzić mechanizm kontroli, ujawniający sytuacje zastosowania przez notariusza błędnej stawki opłaty lub obejścia ustawy przez strony umowy poprzez wskazanie notariuszowi wartości przedmiotu umowy niezgodnego z rzeczywistym stanem rzeczy, od której pobierano opłatę. W pierwszym przypadku, podatnik miał praktycznie dwa wyjścia: zgodzić się z wymiarem opłaty stemplowej przedstawionej nakazem płatniczym lub wnieść stosowne odwołanie do Izby Skarbowej. Istotne jest to, że pomimo błędu notariusza to sam podatnik w toku procesu odwoławczego musiał de facto bronić stanowiska urzędnika. Zaniżenie natomiast wartości transakcji, czyli świadome podanie notariuszowi stanu faktycznego niezgodnego z rzeczywistością, było już przestępstwem zagrożonym karą. W obu tych przypadkach dochodziło do uszczuplenia dochodów Skarbu Państwa, jednak różne były konsekwencje ponoszone przez podatnika. Pomimo tego ustawodawca nie zdecydował się na wprowadzenie obowiązku przedstawiana każdorazowego aktu notarialnego sprzedaży nieruchomości, co pozwoliłoby na szybką weryfikację tak zastosowanej stawki, jak i wartości umowy.
\end{abstract}

Słowa kluczowe: opłata stemplowa, kontrola stemplowa, notariusz, okres międzywojenny

Summary: The Act of July 1, 1926 on stamp duty finally removed the provisions of the partitioning powers from the Polish legal order, eliminating the divergence of the regulations, legislative complexity, uneven treatment of the subject of taxation, and archaic methods of paying the stamp duty. At the same time, until 1933, separate provisions for former Galicia were maintained. As a consequence, we can only talk about the unification of the type of stamp duties charged, while maintaining separate rules for the manner of collecting them. The stamp duty itself was nothing more than a special type of cash benefit collected by the State from all letters confirming legal action and from legal acts not in writing. In order to facilitate the system of collecting stamp 
duties, the legislator gave the notary public the attribute of an official authority, responsible for its calculation and collection. In view of this solution, the legislator had to introduce a control mechanism that was to disclose situations where such a notary would make an error, by applying an incorrect rate of stamp duty or bypassing the act by the parties to the contract, by indicating to the notary public the value of the subject of the contract which is incompatible with the actual state of affairs from which the stamp duty was charged. In the first case, the taxpayer had practically two options: to agree with the size of the stamp duty presented by the payment order or to lodge an appropriate appeal to the Tax Chamber. It is important that, despite the notary's error, it was the taxpayer himself who had de facto defended the notary's position during the appeal process. On the other hand, underestimating the value of the transaction, that is, knowingly giving a notary a false statement actual state of fact, was already a criminal offence. In both cases, there was a decrease in the State Treasury's income, but the consequences for the taxpayer were different. Despite this, the legislator did not decide to introduce an obligation to present each notary deed of sale, which would allow for a quick verification of both the rate and value of the contract used.

Key words: stamp duties, stamp control, notary public, interwar period

Резюме: Закон от 1 июля 1926 года о гербовом сборе окончательно исключил из польского правового порядка положения государств, разделивших Речь Посполитую, устранив расхождения в нормативных актах, законодательную сложность, неравномерное представление объекта налогообложения и архаичные методы уплаты гербового сбора. В то же время, до 1933 года сохранялись отдельные положения для районов бывшей Галиции. Поэтому можно говорить лишь об унификации вида взимаемого гербового сбора при сохранении отдельных правил и порядка его взимания. Сам сбор был не чем иным, как особым видом денежного платежа, взимаемого государством со всех писем, подтверждающих судебный иск, и с судебных исков, не оформленных в письменном виде. В целях упрощения системы взимания гербового сбора законодатель наделил нотариуса статусом официального органа, ответственного за начисление и взимание сбора. В связи с таким решением законодателю необходимо было ввести механизм контроля, раскрывающий ситуации, когда нотариус применяет неверный размер сбора или стороны договора обходят закон, указывая нотариусу стоимость предмета договора, по которому взимался сбор, не соответствующую реальному положению дел. В первом случае у налогоплательщика было два варианта решения: мог согласиться со ставкой гербового сбора, представленной платежным поручением, или подать соответствующую апелляцию в Налоговую палату. Важно, что, несмотря на ошибку нотариуса, именно налогоплательщику пришлось de facto отстаивать позицию чиновника во время апелляционного процесса. Занижение стоимости сделки, то есть намеренное предоставление нотариусу фактов, противоречащих действительности, уже являлось наказуемым преступлением. В обоих случаях доход государственной казны был сокращен, но последствия для налогоплательщика были разными. Несмотря на это, законодатель не принял решения о введении обязанности предъявления каждого нотариального акта о продаже недвижимости, что позволило бы быстро проверить как применяемую ставку, так и стоимость договора.

Ключевые слова: гербовый сбор, гербовый контроль, нотариус, межвоенный период

\section{Wstęp}

Celem niniejszego artykułu jest wskazanie skutków prawnych, będących następstwem przeprowadzanej kontroli stemplowej aktów notarialnych (umów sprzedaży nieruchomości) przez władze skarbowe, podczas których stwierdzono uiszczenie opłaty stemplowej w oparciu o błędnie zastosowaną stawkę lub celowo zaniżono wartości transakcji, przy czym w obu tych sytuacjach dochodziło do uszczuplenia Skarbu Państwa poprzez pobranie opłaty stemplowej przez notariusza w niewłaści- 
wej, tj. zaniżonej, kwocie. Te dwie, wydawać by się mogło, podobne sytuacje, które w stosunku do Skarbu Państwa wywierały identyczny skutek, tak w stosunku do podatnika pociągały za sobą diametralnie różne konsekwencje prawne.

\section{Ustawa o opłatach stemplowych - konstrukcja prawa i przedmiot regulacji}

Opłata stemplowa funkcjonowała na mocy ustawy z dnia 1 lipca 1926 r. o opłatach stemplowych ${ }^{1}$. Ten akt prawny według większości współczesnych badaczy ${ }^{2}$ wpisywał się w tendencję unifikacji systemu podatkowego poprzez wprowadzenie w tym przypadku - jednolitych zasad poboru opłaty stemplowej dla całego kraju. Jakkolwiek teza mówiąca o unifikacji może wydawać się prawidłowa, tak już po analizie treści art. 17, 29, 172 i 173 ustawy stemplowej, nie mogę się z nią zgodzić. Ustawodawca utrzymał do 1934 r. w mocy przepisy austriackie na obszarach województw krakowskiego, lwowskiego, stanisławowskiego i tarnopolskiego, ulegając naciskom notariuszy z tych terenów, czym w sposób oczywisty sprzeniewierzył się idei unifikacji prawa podatkowego. Stanisław Stein na łamach „Przeglądu Notarialnego” pisał, że wprowadzenie tych przepisów ostatecznie uczyniło „[...] z ustawy karykaturę ustawodawczą, kłócącą się z przepisami innych obowiązujących ustaw, a nawet z konstytucją"3. Dodatkowo, na mocy art. 29 ustawy stemplowej, notariuszy z tych terenów pozbawiono przymiotu „urzędnika skarbowego” w zakresie wymiaru poboru opłaty stemplowej, czym uczyniono wyłom od zasady ogólnej wyrażonej w art. 17 ustawy stemplowej. Na terenach, gdzie obowiązywał austriacki kodeks cywilny, istniał jedynie obowiązek przesyłania do urzędu skarbowego odpisu sporządzonych przez notariusza aktów, celem następnie wymierzenia stosownej opłaty stemplowej przez ten urząd ${ }^{4}$. Wyjątek ten został usunięty z polskiego (dbiegu

1 Ustawa z dnia 1 lipca 1926 r. o opłatach stemplowych, Dz. U. Nr 98, poz. 570, tekst jednolity: Dz. U. z 1935 r. Nr 64, poz. 404 (dalej: ustawa stemplowa).

2 Zob. M. Kępa, Ewolucja opodatkowania obrotu niezawodowego w Polsce w latach 1918-1947, Studia Iuridica Lublinensia 2010, t. 14, s. 23-41; D. Antonów, Unifikacja opłat stemplowych w okresie rządów sanacji - ustawa z 1 lipca 1926 roku o opłatach stemplowych, Studia Nad Autorytaryzmem i Totalitaryzmem 2018, t. 40, nr 4, s. 138; D. Antonów, Opłata skarbowa w polskim porządku prawnym, Warszawa 2017, s. 74-75. Zob. też J. Gliniecka, Prawna ewolucja konstrukcji przedmiotu opłaty skarbowej w polskim systemie dochodów samorzq̨dowych, Gdańskie Studia Prawnicze 2015, t. 34, s. 277-278.

3 S. Stein, Kilka uwag o zastosowaniu praktycznem nowej ustawy stemplowej, Przegląd Notarjalny 1927, nr 1, s. 53-54.

4 W sprawie wykładni ustawy stemplowej, Przegląd Notarjalny 1927, nr 1, s. 90; L. Cichowicz, Anytomia pomiędzy art. 28 ust. 2 a art. 27 liczba 1 oraz art. 1, 5, 10 ustawy stemplowej, dalej ordynacja notarjacka 
prawnego dopiero na mocy art. 148 ust. 1 pkt 6 rozporządzenia Prezydenta Rzeczypospolitej z dnia 27 października 1933 r. - Prawo o notarjacie ${ }^{5}$, wprowadzając od 1934 r. jednolite zasady dla polskiego notariatu.

Czym jednak była opłata stemplowa? Niczym innym jak „szczególnego rodzaju świadczeniem pieniężnym" pobieranym przez państwo od wszelkich pism stwierdzających czynność prawną oraz od czynności prawnych niesporządzonych $\mathrm{w}$ formie pisemnej. Przez pisma należało rozumieć nie tylko te podpisane przez dwie strony, lecz także te podpisane przez jedną stronę, jeżeli zostały one wręczone stronie drugiej bądź przedstawione sądowi celem dokonania wpisu hipotecznego. Ustawodawca opodatkował czynności prawne, od których nie pobierał innych podatków pośrednich, jak i bezpośrednich, nadając opłacie stemplowej ostatecznie postać podatku od obrotu niezawodowego, ekwiwalentu dla państwa za czynności organów administracyjnych czy wreszcie wynagrodzenia za świadczone usługi, które oferowało państwo na skutek wniesionego podania.

Określony w art. 1 ustawy stemplowej przedmiot opłat stemplowych był bardzo szeroki i obejmował różnego rodzaju świadczenia pieniężne o zróżnicowanej naturze normatywnej. Jednocześnie powiązano obowiązek jej uiszczenia z wniesieniem pisma ${ }^{6}$. Tak szerokie ujęcie wydaje się być konsekwencją już samego tytułu ustawy o opłatach stemplowych. Ustawodawca użył liczby mnogiej, przez co chciał wskazać, że jedną ustawą zamierzał objąć szereg danin publicznych, opłat, a nieujętych w innych ustawach podatkowych. Przyjęcie takiego rozwiązania, czyli zebranie w jeden akt prawny w ramach kategorii opłat stemplowych równego rodzaju danin publicznych, przyczyniło się do jej swoistej nieczytelności i trudności w jej stosowaniu. Była to niestety chyba największa wada ustawy. Szereg zjawisk, ich różnorodność, które miały być ujęte $\mathrm{w}$ akcie prawnym, wiązało się z potrzebą ich dostosowania do danej sytuacji tak przez podatnika, jak i organy urzędowe. Spowodowało to, że wśród opłat stemplowych znaleźć można typowe opłaty (od podań i pism składanych przez petenta jako wynagrodzenie za specjalną usługę), podatki (od sprzedaży nieruchomości jako typowy podatek od obrotu niezawodowego, przyjmujący konstrukcje obecnego podatku od czynności cywilnoprawnych ${ }^{7}$ ) oraz opłaty administracyjne ${ }^{8}$.

w ust.pr. o sadownictwie niepornem z 21 września 1899, Czasopismo Adwokatów Polskich 1927, nr 2, s. 18. Zob. też Kodeks Stemplowy, Lwów 1927, s. 30.

5 Dz. U. Nr 84, poz. 609, dalej: prawo o notarjacie) (pisownia oryginalna).

6 F. Kozioł, Opłaty stemplowe, w: Odrodzona skarbowość polska, Warszawa 1931, s. 73; D. Antonów, Unifikacja opłat..., s. 138.

7 Ustawa z dnia 9 września 2000 r. o podatku od czynności cywilnoprawnych, tekst jednolity: Dz. U. z 2019 r. poz. 1519.

8 D. Antonów, Opłata skarbowa..., s. 74-75. Zob. też J. Gliniecka, Prawna ewolucja..., s. 277-278. 
Stworzenie przejrzystej ustawy, której układ umożliwiałby szybką orientację w odnalezieniu przepisu, było rzeczą niełatwą, a wręcz - jak się okazało - ostatecznie niemożliwą. Powyższe znalazło swoje odzwierciedlenie w rozbudowanej strukturze ustawy. Szczególnie widoczny był brak syntetycznego ujęcia czynności prawnych i należnych od nich opłat. Brak było bowiem zestawienia alfabetycznego przedmiotów i czynności prawnych podlegających opłacie, które przybrałoby np. formę załącznika do ustawy. Powodowało to praktyczne trudności w posługiwaniu się ustawą i szybkim z niej korzystaniu. Swoisty błąd ustawodawcy poprawił m.in. M. Buczma-Czapliński, który w swej pracy przedstawił przegląd najczęstszych opłat stemplowych, przypisując stawkę do danej czynności prawnej lub pisma?.

Pomimo wskazania powyższych dość istotnych „wad” ustawy o opłatach stemplowych, usunęła ona ostatecznie z polskiego porządku prawnego przepisy państw zaborczych, eliminując rozbieżności regulacji, zawiłość legislacyjną, niejednolite ujęcie przedmiotu opodatkowania oraz archaiczne sposoby uiszczania opłaty stemplowej ${ }^{10}$. Jednocześnie do 1933 r. utrzymano przepisy odrębne dla terenów b. Galicji. W konsekwencji można mówić o unifikacji rodzaju pobieranych opłat stemplowych, przy zachowaniu odrębnych zasad i trybu ich pobierania.

\section{Sposób obliczania i uiszczenia opłaty od aktów sporządzanych przez notariusza}

Za podstawę wymiaru opłaty stemplowej traktowana była co do zasady ogólna wartość podana przez samego podatnika, jako wartość całego przedmiotu umowy, choćby z pisma wynikało, że umowa została całkowicie wykonana. Jeżeli jednak wartości takiej nie można było ustalić (jak np. w przypadku umowy na dostawy płodów rolnych czy dzierżawy zawartej na czas nieokreślony), wówczas ustalano podstawę w trakcie wykonywania umowy (art. 6 ustawy stemplowej).

W związku z faktem, że wartość umowy zależała od jej stron, ustawodawca wypracował mechanizm nakazujący podatnikom określanie ceny przedmiotu umowy według ściśle określonych zasad, aby uniknąć zaniżania ich wartości przez strony umowy, co w konsekwencji prowadziło do zapłacenia opłaty stemplowej w wysokości niższej i uszczuplenia Skarbu Państwa (art. 6-13 ustawy stemplowej). Odnosząc

9 M. Buczma-Czapliński, Poradnik prawniczy, Lwów-Warszawa-Poznań 1932, s. 416.

10 A. Rosenkranz, Zasady wytyczne projektu ustawy o opłatach stemplowych, Warszawa 1924, s. 11. Zob. też B. Markowski, Podatki od obrotów i opłaty, Warszawa 1924, s. 4-6. 
to do umów sprzedaży nieruchomości, bez znaczenia była np. sytuacja okazyjnego jej zakupu, gdyż opłata stemplowa zgodnie z art. 12 ustawy stemplowej obliczana była od wartości rynkowej nieruchomości.

Przepis art. 15 ustawy stemplowej określał krąg osób, na których ciążył obowiązek uiszczenia opłaty stemplowej na zasadach odpowiedzialności solidarnej. W zakresie pism stwierdzających umowę były to: osoby będące jej stronami; osoba, która zawarła umowę, prowadząc sprawy bez zlecenia, oraz każdy posiadacz pisma lub uwierzytelnionej kopii, lub tłumaczenia. W zakresie orzeczeń były to wszystkie osoby, które na podstawie orzeczenia nabyły prawo.

Cechą charakterystyczną konstrukcji opłaty stemplowej był sposób jej obliczania i uiszczania, $\mathrm{tj}$. bez wymiaru urzędowego oraz na jego podstawie. W pierwszym przypadku to podatnik sam obliczał wysokość należnej opłaty stemplowej, odnosząc się do wartości przedmiotu umowy i stosowego jej wymiaru. W drugim przypadku opłatę obliczał i wymierzał organ urzędowy, czyli urzędy skarbowe, notariusze, sądy lub urzędy państwowe, opierając się na wartościach podanych przez strony umowy i następnie dopasowując odpowiednią stawkę przewidzianą ustawą stemplową. Szczególną rolę w zakresie poboru opłaty stemplowej odgrywał właśnie notariusz, który - jak wykazano powyżej - uzyskał przymiot „urzędnika skarbowego". Miał on bowiem z tego tytułu obowiązek wymierzyć opłatę stemplową od wszystkich sporządzanych przed nim aktów, przedstawionych mu celem dokonania czynności urzędowej pism oryginalnych, ich wtóropisów, odpisów lub tłumaczeń czy sprzedaży dokonanych przed nim w drodze licytacji, a następnie odprowadzić pobrane opłaty do właściwego urzędu. Oczywiście opłaty tej nie wymierzano, gdy ta uprzednio została już uiszczona lub wymierzona i pobrana przez inny organ urzędowy. Wówczas notariusz nie badał prawidłowości jej uiszczenia (art. 27 ustawy stemplowej). Notariusz stał się nie tylko poborcą tej opłaty, ale był też zobowiązany jako urzędnik do jej wymierzenia, a następnie pobrania ${ }^{11}$.

Opłata stemplowa wymierzona przez notariusza uiszczana była bezpośrednio do jego rąk i wyłącznie gotówką. Ciekawe rozwiązanie przewidywał art. 28 ust. 2 ustawy stemplowej, zgodnie z którym notariusz miał obowiązek wstrzymania się od dokonania czynności urzędowej, jeżeli nie uiszczono opłaty. Z treści tego przepisu wynikało wprost, że notariusz pobierał opłatę stemplową jeszcze przed dokonaniem czynności. Takie rozwiązanie prowadziło w rzeczywistości do sytuacji, kiedy to faktycznie opłacie podlegała czynność jeszcze niedokonana, czym przepis art. 28 ust. 2 stał w sprzeczności z art. 1, 6 i 27 pkt 1 ustawy stemplowej,

11 A. Rosenkranz, Zasady wytyczne..., s. 19. 
stanowiących o opłacie od sporządzonych przed notariuszem aktów notarialnych ${ }^{12}$. Niestety, przepis w tej treści nie został zmieniony. Jeżeli strona nie chciała opłacić wymierzonej opłaty stemplowej, notariusz stosował „przymus”, mianowicie odmawiał sporządzenia aktu ${ }^{13}$. Na odmowę nie przysługiwało zażalenie. Co więcej, art. 66 $\$ 5$ prawa o notarjacie dawał notariuszowi prawo odnowy sporządzenia aktu, gdy ten zmierzał do obejścia ustawy stemplowej.

Z uwagi na fakt, że notariusz był organem urzędowym, mógł on wymierzyć również podwyżkę stemplową w sytuacji, gdy powziął informację, że od przedstawionych mu pism oryginalnych celem dokonania np. ich odpisu czy wtóropisu nie uiszczono opłaty stemplowej. Wówczas przed czynnością wzywał strony, by podwyżkę zapłacono do jego rąk. W takiej jednak sytuacji notariusz nie mógł wstrzymać się od czynności urzędowej, miał jednak obowiązek zawiadomić właściwy urząd skarbowy o tym fakcie (art. 28 ust. 3 ustawy stemplowej).

Notariusz w ściśle określonych terminach pobrane opłaty stemplowe wpłacał do kasy urzędu, tj. od aktów sporządzonych od 1. do 7. dnia każdego miesiąca w 8. dniu tego miesiąca, od 8. do 14. dnia każdego miesiąca wpłaty dokonywano 15 . dnia tego miesiąca, od 15. do 21. dnia każdego miesiąca wpłaty dokonywano 22. dnia tego miesiąca i od 22. do końca każdego miesiąca wpłaty dokonywano 1. dnia nowego miesiąca. Jeżeli termin płatności przypadał na dzień wolny, opłaty wnoszono w najbliższy dzień powszechny. Notariusz miał również obowiązek sporządzania i wnoszenia do urzędu skarbowego deklaracji podatkowej pobranych opłat ${ }^{14}$. W sytuacji, gdy podatnik samodzielnie obliczał wysokość opłaty stemplowej, należało uiścić ją w ciągu 3 tygodni od dnia sporządzenia pisma (art. 20 ust. 1 ustawy stemplowej).

\section{Rewizja aktów notarialnych}

Notariusz nie miał obowiązku przekazywania organom nadzoru sporządzonych przed nim aktów notarialnych. Odstępstwo od tej zasady wprowadziły jedynie: wspomniany już przepis art. 29 ustawy stemplowej obowiązujący w byłym zaborze austriackim, stanowiący o konieczności przedstawiania urzędowi skarbowemu

12 L. Cichowicz, Anytomia..., s. 17.

13 A. Rosenkranz, Notarjusz jako poborca opłat stemplowych. Kilka założeń ogólnych w związu ze sprawa „Ofert co do nieruchomości”, Przegląd Notarjalny 1934, nr 6, s. 123.

$14 \$ 60$ Rozporządzenia Ministra Skarbu z dnia 20 listopada 1926 r. zawierającego przepisy wykonawcze do ustawy z dnia 1 lipca 1926 r. o opłatach stemplowych, Dz. U. Nr 123, poz. 713 (dalej: przepisy wykonawcze). 
uwierzytelnionych przed nim aktów notarialnych, oraz art. 28 ust. 5 tej ustawy odnoszący się do świadczeń okresowych lub tych, co do których nie można określić wartości świadczenia ${ }^{15}$. Wówczas to urząd skarbowy wymierzał opłatę skarbową na podstawie dostarczonego mu aktu i ten, jako jedyny, mógł wszcząć postępowanie w zakresie sprawdzenia, czy np. cena sprzedawanej nieruchomości była rynkowa, czyli zgodna z rzeczywistością w świetle postanowień art. 12 ustawy stemplowej.

$\mathrm{W}$ jakim zatem trybie nadzoru organy skarbowe mogły zakwestionować tak wartość przedmiotu umowy, jak i ewentualnie stawkę opłaty stemplowej przyjętą przez notariusza? W pierwszej kolejności, jeżeli urząd państwowy spostrzegł, że od pisma przedstawionego mu celem dokonania czynności urzędowej nie uiszczono opłaty lub uiszczono ją w niewłaściwej wysokości, zawiadamiał o tym urząd skarbowy. Zawiadomienie takie mógł wnieść również sam notariusz, jeżeli według jego wiedzy zaniżono wartość przedmiotu transakcji, przez co odprowadzono opłatę w niewystraczającej wysokości (art. 35 ustawy stemplowej). Przepisu tego nie stosowano oczywiście w przypadku zapłacenia już opłaty stemplowej na podstawie wymiaru urzędowego. Wówczas notariuszowi przedstawiono przed czynnością zaświadczenie z urzędu skarbowego o uiszczeniu należnej opłaty.

Wobec braku obowiązku przekazywania aktów notarialnych urzędom skarbowym ustawodawca zdecydował się na wprowadzenie przepisów pozwalających kontrolować wysokość pobranych opłat w przedmiocie ich prawidłowego wymiaru czy podstawy opodatkowania. W pierwszej sytuacji, notariusz mógł popełnić błąd i zastosować błędną stawkę opłaty stemplowej. W drugim przypadku pobrał on opłatę stemplową według prawidłowej stawki, jednak strony umowy zaniżyły wartość przedmiotu umowy. W obu tych sytuacjach dochodziło do uszczuplenia Skarbu Państwa. Szczególnie istotny był drugi przypadek, gdyż notariusz zgodnie z przytoczonym już art. $66 \$ 5$ prawa o notarjacie mógł odmówić czynności urzędowych, gdyby mogło dojść do obejścia ustawy stemplowej. Z drugiej strony pojawiają się pytania: czy można było wymagać od notariusza, aby ten miał wiedzę na temat wartości sprzedawanej nieruchomości, której cena mogła zależeć od tak wielu czynników, że trudno od notariusza - w oparciu o doświadczenia i wiedzę życiową - wymagać tak specjalistycznej wiedzy? Dlaczego miano obarczać notariusza obowiązkiem badania, czy cena sprzedaży ma charakter rynkowy? Po pierwsze, nie miał on ku temu żadnych instrumentów, po drugie - ustawa musiałyby na strony umowy nakładać np. obowiązek przedłożenia opinii rzeczoznawcy czy oszacowanie dokonane przez np. bank stwierdzające, że wartość sprzedawanej nieruchomości jest rynkowa. Ewentualnie notariusz, po powzięciu według swojej 
wiedzy, iż wartość jest zaniżona, powinien wstrzymać się od sporządzenia pisma i wezwać strony do udokumentowania wartości transakcji. Ustawodawca jednak takiego obowiązku na notariusza, jak i na strony umowy nie nałożył.

Zdarzenia powyższe weryfikowane były wyłącznie w trybie kontroli nadzorczej, która zgodnie z $\$ 78$ przepisów wykonawczych nazwana zastała „kontrolą stemplową" aktów notarialnych przeprowadzaną przez władze skarbowe w zakresie tak prawidłowego przyporządkowania stawki opłaty stemplowej do pisma, jak i prawidłowości wskazania przez strony umowy stanu faktycznego zgodnego z rzeczywistością. W przypadku zakwestionowania wysokości wymiaru opłaty stemplowej z uwagi na nieprawidłową stawkę właściwe władze skarbowe wymierzały osobom zobowiązanym do uprzedniego uiszczenia opłaty stemplowej nakaz płatniczy w trybie art. 33 ust. 2 ustawy stemplowej. Natomiast, gdy strony umowy podały świadomie wartość przedmiotu transakcji niezgodnie z rzeczywistością, tj. zaniżyły celowo jej wartość lub doszło do zapłacenia ceny w rzeczywistości wyższej od tej podanej w umowie, w wyniku czego doszło do niepobrania opłaty lub pobrania jej w niższej wysokości, solidarnie osoby te podlegały sankcji karnej określonej w art. 40 ustawy stemplowej, tj. karze pieniężnej w wysokości do piętnastokrotności kwoty nieuiszczonej opłaty stemplowej. To wyłącznie organy skarbowe dysponowały instrumentami prawnymi, aby sprawdzić, czy cena sprzedawanej nieruchomości odpowiadała wymaganiom wynikającym z art. 12 ustawy stemplowej. Ostatecznie doprowadziło to do przyjęcia rozwiązania, kiedy to za wartość wymiaru opłaty stemplowej nie brano wartości umowy, ale cenę oszacowaną w trybie nadzoru w oparciu o wytyczne ustawy. Podatnik nie miał oczywiście obowiązku zapłacenia stronie umowy części kwoty wynikającej z różnicy ceny określonej w umowie, a tej oszacowanej $\mathrm{w}$ trybie postępowania na gruncie art. 40 ustawy stemplowej. Szacowanie to miało jedynie wpływ na wysokość długu wobec Skarbu Państwa.

Urzędnik, który stwierdzał naruszenie przepisów ustawy stemplowej, sporządzał stosowny protokół, okazywany w pierwszej kolejności notariuszowi, który mógł wnieść do takiego protokołu swoje uwagi. Następnie wystawiano nakaz płatniczy lub sprawę kierowano do właściwego prokuratora celem wszczęcia postępowania.

\subsection{Rewizja aktów notarialnych w przypadku stwierdzenia zastosowania nieprawidłowej stawki opłaty stemplowej}

Jak już wykazano, ustawa w swojej treści była bardzo skomplikowana i nastręczała podatnikom czy organom urzędowym wiele trudności. Niejednokrotnie podatnik, na skutek rozbudowanego katalogu opłat i ich wysokości, błędnie przyporządko- 
wywał stawkę opłaty stemplowej do danego pisma. Błędu tego nie ustrzegali się również sami notariusze. Ze zrealizowanej przez autora artykułu kwerendy archiwalnej wynika, że w wyniku przeprowadzanych czynności nadzorczych przez władze skarbowe stosunkowo często wystosowywano wobec podatników nakazy płatnicze, wynikające z kontroli pism, od których nie odprowadzono opłaty stemplowej w odpowiedniej wysokości w wyniku zastosowania przez notariusza niewłaściwej stawki ww. należności. Pomimo jego oczywistego błędu, ostatecznie to jednak podatnik ponosił konsekwencje takiej pomyłki. Urząd skarbowy kierował bowiem do stron umowy nakaz płatniczy, ze wskazaniem prawidłowej stawki i kwoty do zapłaty, podając jednocześnie podstawę prawną według niego prawidłowego wymiaru. Co ważne, na podatnika w takiej sytuacji nie nakładano $\mathrm{z}$ tego tytułu żadnych sankcji o charakterze karno-skarbowym. Miał on obowiązek jedynie zapłacić brakującą część opłaty stemplowej w terminie określonym nakazem.

Obrazując sytuację, odnosząc się do konkretnego przypadku, dnia 14 stycznia 1933 r. ordynat Maurycy Zamoyski sprzedał Gitli Lichter część dóbr ordynackich pod nazwą „Osada Młyńska w Bononji” zlokalizowanych w powiecie biłgorajskim o powierzchni 9,0744 ha wraz z folwarkiem za łączną cenę 16000 zł. W skład majątku wchodził młyn z prawem wodnym. Notariusz od powyższej czynności pobrał gotówką $160 \mathrm{zł}$ opłaty stemplowej od umowy sprzedaży ${ }^{16}, 10 \mathrm{zł}$ od wypisu, $5 \mathrm{zł}$ od deklaracji ${ }^{17}, 5 \mathrm{zł}$ od upoważnienia ${ }^{18}$, od $180 \mathrm{zł} 10 \%$ dodatek w wysokości $18 \mathrm{zt}^{19}$ oraz $80 \mathrm{zł}$ podatku komunalnego ${ }^{20}$, czyli $50 \%$ wymiaru opłaty stemplowej od umowy sprzedaży, w sumie pobrano $278 \mathrm{zł}^{21}$.

Istotny $\mathrm{w}$ całej sprawie jest fakt, że sprzedaż ta była efektem przeprowadzonej w 1925 r. reformy rolnej, w ramach której rozdysponowano dobra ordynackie o powierzchni 256 ha. Zgodnie z założeniem reformy miała ona umożliwić zakup nieruchomości gruntowych poprzez udzielenie preferencyjnych kredytów na powiększenie lub stworzenia niezależnych ekonomicznie gospodarstw rolnych, a właścicielom parcelowanych majątków gwarantować zapłatę za przekazane grunty po cenach rynkowych ${ }^{22}$. W pierwszej kolejności zdobycie nieruchomości

16 Zgodnie z art. 58 ust. 3 opłacie stemplowej $1 \%$ podlegały pisma stanowiące przejścia własności nieruchomości, przeprowadzonych na zasadzie przepisów o reformie rolnej.

17 Art. 139 ust. 1 ustawy stemplowej.

18 Art. 111 ust. 1 ustawy stemplowej.

19 Ustawa z dnia 12 lutego 1931 r. o poborze 10\% dodatku do niektórych podatków i opłat stemplowych, Dz. U. Nr 16, poz. 82.

20 Art. 13 ust. 1 ustawy z dnia 2 sierpnia 1925 r. o tymczasowem uregulowaniu finansów komunalnych, Dz. U. z 1932 r. Nr 106, poz. 884.

21 Archiwum Państwowe w Lublinie 35/71/0/5.8/21644.

22 Ustawa z dnia 28 grudnia 1925 r. o wykonaniu reformy rolnej, Dz. U. z 1926 r. Nr 1, poz. 1. 
umożliwiło Orzeczenie Prezesa Okręgowego Urzędu Ziemskiego w Lublinie z dnia 16 stycznia 1932 r. zatwierdzające sposób parcelacji dla nieruchomości ziemskiej pod nazwą „Osada Młyńska w Bononji”, i zezwoliło na jej sprzedaż ${ }^{23}$. Co ważne, sprzedane grunty były wolne od wszelkich obciążeń hipotecznych na mocy art. 7 rozporządzenia Prezydenta Rzeczypospolitej z dnia 23 sierpnia 1932 r. $^{24}$

W omawianym stanie faktycznym notariusz zastosował stawkę preferencyjną opłaty stemplowej w wysokości $1 \%$ wartości pisma, gdyż według niego sprzedaż nieruchomości była wynikiem przeprowadzonej parcelacji nieruchomości rolnych, dokonanej na podstawie przepisów o reformie rolnej (art. 58 ust. 3 ustawy stemplowej), dającej prawo do zastosowania preferencyjnej stawki. Podstawowa stawka od pism stwierdzających umowę nabycia nieruchomości wynosiła 4\% (art. 58 ust. 1) ${ }^{25}$. Fakt zastosowania przez notariusza obniżonej stawki pozwala przyjąć, iż notariusz uznał, że skoro sprzedaż odbywała się $\mathrm{w}$ ramach parcelacji po uprzedniej zgodzie urzędu ziemskiego, to sprzedawana osada młyńska tworzyła w myśl art. 1 ust. 2 pkt a ustawy o wykonaniu reformy rolnej samodzielne gospodarstwo rolne, co było warunkiem sine qou non celu reformy agrarnej ${ }^{26}$.

Urząd Skarbowy w Biłgoraju wydał dnia 18 października 1933 r. nakaz płatniczy stwierdzający, iż na podstawie art. 52 i 58 ustawy stemplowej wymiar podatku powinien wynieść $4 \%$, czyli 640 zł oraz 320 zł dodatku komunalnego, razem 960 zł. Po potrąceniu uiszczonych $240 \mathrm{zł}$ do zapłaty pozostało 720 zł. Dodatkowo nakazano

23 Parcelacja przeznaczonych dóbr rozpoczęto orzeczeniem Urzędu Ziemskiego z dnia z dnia 30 grudnia $1927 \mathrm{r}$.

24 Rozporządzenie Prezydenta Rzeczypospolitej z dnia 23 sierpnia 1932 r. w sprawie wyłączeń z Ordynacji Zamoyskiej, Dz. U. Nr 74, poz. 666.

$25 \mathrm{~W} \S 103$ rozporządzenia wykonawczego ustawodawca wprost wskazał, że opłacie w wysokości 1\%, przewidzianej w art. 58 ust. 3 ustawy stemplowej, podlegały orzeczenia urzędów ziemskich ustalające przejście prawa własności przy parcelacji oraz umowy o sprzedaż $\mathrm{w}$ formie parcelacji, wymienione w powołanej ustawie.

26 Art. 58 ust. 3 ustawy stemplowej wprost odnosił się do przejścia własności przy parcelacji przeprowadzanej na zasadzie przepisów o reformie rolnej. Ustawodawca jednak nie zdefiniował pojęcia parcelacji, co powodowało wiele niejasności w jej interpretacji. Jakkolwiek parcelacją był każdy podział gruntu, choćby jednorazowy. Zatem ulga w opłacie skarbowej miała zastosowanie wszędzie tam, gdzie miał miejsce akt podziału, a następnie odpłatne przeniesienie własności nieruchomości dóbr tabularnych na rzecz osoby drugiej. Każda taka transakcja podlegała pod kompetencje Okręgowego Urzędu Ziemskiego, zgodnie z $\$ 52$ rozporządzenia z dnia 12 marca 1924 r., Dz. U. Nr 28, poz. 281, a tym samym była ona parcelacją w myśl przepisów o reformie rolnej, gdyż jak stanowił art. 46 ust. 2 ustawy o wykonaniu reformy rolnej, wszelka parcelacja podlegała pod przepisy tej ustawy. Jakkolwiek ustawa stemplowa w zakresie zastosowania stawki preferencyjnej odnosiła się do art. 1 tej ustawy, a więc chodziło o urzeczywistnienie przebudowy systemu rolnego kraju. L. Zakrocki, Na drogach i bezdrożach ustawy stemplowej, Przegląd Notarjalny 1928, nr 1-2, s. 160-161 oraz W. Jaworski, Obrót ziemią w obecnym ustawodawstwie, Przegląd Notarjalny 1930, nr 1-2, s. 1-5. Zob. też W. Jaworski, Reforma rolna a hipoteka $i$ kataster, Przegląd Notarjalny 1928, nr 2, s. 122-124. 
zapłacenie $10 \%$ od 480 zł. Po zsumowaniu wszystkich kwot wezwano strony solidarnie do zapłaty $768 \mathrm{zł} \mathrm{w}$ terminie do 7 dni od dnia doręczenia wezwania. Jednocześnie pouczono o możliwości wniesienia w ciągu miesiąca skargi do urzędu wydającego nakaz ${ }^{27}$.

W analizowanej sprawie, pomimo solidarnego zobowiązania, odwołanie z dnia 11 grudnia 1933 r. do Lubelskiej Izby Skarbowej wniósł jedynie sprzedający, za pośrednictwem urzędu wydającego nakaz płatniczy ${ }^{28}$. Podstawą odwołania był zarzut naruszenia art. 1 ust. 2 pkt a ustawy o wykonaniu reformy rolnej, ponieważ sprzedaż nieruchomości była konsekwencją podziału dóbr ordynackich, a według odwołującego się powstało samodzielne gospodarstwo rolne o powierzchni poniżej 20 ha, co pozwalało zastosować stawkę 1\%. Dalej wskazano, że zgodnie z art. 27, 28 ust. 3 i 58 ust. 3 ustawy stemplowej oraz zgodnie z ustawą o reformie rolnej to notariusz dokonał stosownego obliczenia opłaty i pobrał ją w wysokości przewidzianej prawem i to urząd skarbowy powołał się błędnie - według odwołującego - na art. 52 i 58 ust. 1 ustawy stemplowej, przyjmując stawkę opłaty w wysokości $4 \%$, a nie $1 \%$. Wskazano również, że zgodnie ze statutem ordynacji zatwierdzonym przez Sejm Walny w 1589 r. jej grunty są niezbywalne, a jeżeli już, to ich sprzedaż może nastąpić wyłącznie $\mathrm{w}$ sytuacjach szczególnych, m.in. tych określonych $\mathrm{w}$ art. 77 ustawy o reformie rolnej. Jak wynika $\mathrm{z}$ treści umowy sprzedaży z dnia 14 stycznia 1933 r., sprzedaż folwarku nastąpiła w ramach reformy rolnej, w szczególności w granicach zakreślonych w art. 50 tej ustawy, gdyż obszar nowopowstałego gospodarstwa nie przekraczał $20 \mathrm{ha}^{29}$. Dlatego też opłata stemplowa została wymierzona w wysokości prawidłowej. Wniesiono o uchylenie zaskarżonego nakazu płatniczego i o zawiadomienie pełnomocnika o treści podjętej decyzji.

W odpowiedzi na wniesione odwołanie Izba Skarbowa decyzją z dnia 5 stycznia 1939 r. nie uwzględniła odwołania, stwierdzając, że wymiar dokonany przez urząd skarbowy w Biłgoraju był prawidłowy. Izba orzekła, iż zarzuty, że obszar nabytej działki nie przekraczał 20 ha, grunty zaś były alienowane na podstawie art. 77 ustawy o wykonaniu reformie rolnej, nie są trafne. Przepis ust. 3 art. 58 ustawy stemplowej był wyjątkiem od zasady ogólnej i nie podlegał wykładni rozszerzającej, ponadto stosowany mógł być on wyłącznie w wypadkach ściśle określonych przez ustawodawcę. Obniżonej stawce podlegały tylko parcelacje określone w art. 50 i 51 ustawy o reformie rolnej, czyli kreujące gospodarstwa rolne zdrowe

27 Termin miesięczny na odwołanie od nakazu płatniczego określał art. 46 ust. 1 ustawy stemplowej.

28 Art. 47 ust. 1 ustawy stemplowej - wydający nakaz, przekazując akta organowi odwoławczemu wraz $\mathrm{z}$ dokumentacją, przedstawiał swoją opinię w sprawie.

$29 \$ 7$ Rozporządzenie Prezydenta Rzeczypospolitej z dnia 23 sierpnia 1932 r. w sprawie wyłączeń z Ordynacji Zamoyskiej, Dz. U. Nr 74, poz. 666. 
i wydolne produkcyjnie, ewentualnie usuwające ich karłowatość. Przedmiotem sprzedaży była jednak osada młyńska wraz z młynem i prawem wodnym, która w ocenie Izby Skarbowej nie była gospodarstwem rolnym, przez co niemożliwe było zastosowanie preferencyjnej stawki opłaty skarbowej. Bez znaczenia był fakt, że sprzedaży dokonano $\mathrm{w}$ ramach parcelacji, skoro nie powstało samodzielne gospodarstwo rolne. Orzeczenie było ostateczne, stronie przysługiwała jedynie skarga do Najwyższego Trybunału Administracyjnego ${ }^{30}$.

\subsection{Rewizja aktów prawnych w przypadku świadomego podania stanu faktycznego niezgodnego z rzeczywistością}

Procedura odwoławcza opisana powyżej nie miała zastosowania w przypadku stwierdzenia przestępstwa określonego $\mathrm{w}$ art. 40 ustawy stemplowej. W sytuacji ujawnienia przez władze nadzorcze zaniżenia wartości przedmiotu umowy, te miały obowiązek zawiadomienia o tym fakcie właściwego prokuratora przy sądzie okręgowym z uwagi na fakt, że czyn ten był przestępstwem. Co ważne, postępowanie mogło być zainicjowane bez wniosku władz skarbowych ( $\$ 80$ przepisów wykonawczych). Sprawa rozpatrywana była w składzie jednoosobowym. Od orzeczenia pierwszej instancji przysługiwała apelacja ${ }^{31}$.

Podobnie jak w poprzedniej sytuacji odniesiono się do konkretnego stanu faktycznego, co pozwoli wnikliwie przeanalizować i zrozumieć praktyczne funkcjonowanie art. 40 ustawy stemplowej. W wyniku przeprowadzonej rewizji aktu notarialnego z dnia 12 kwietnia 1932 r. stwierdzającego sprzedaż nieruchomości władze skarbowe zakwestionowały cenę majątku jako zaniżoną, przez co doszło do pobrania opłaty skarbowej w niższej wysokości i skierowały sprawę do właściwego prokuratora celem sporządzenia i skierowania do sądu aktu oskarżenia. W efekcie przeprowadzonego postepowania wyjaśniającego prokurator $\mathrm{w}$ sprawie o sygn. I Ds. 90/37 z dnia 31 marca 1937 r. oskarżył Marię Wolską o popełnienie przestępstwa przewidzianego $\mathrm{w}$ art. 40 ustawy stemplowej, tj. o świadome podanie podczas zawierania umowy sprzedaży nieruchomości w Lublinie zaniżonej wartość nabywanej nieruchomości, a mianowicie 4000 zł zamiast 73143 zł, czym spowodowała za niski wymiar opłaty stemplowej i uszczuplenie Skarbu Państwa. Sprawę skierowano do Sądu Okręgowego w Lublinie celem jej rozpoznania ${ }^{32}$.

30 Archiwum Państwowe w Lublinie 35/71/0/5.8/21644.

31 Art. 19, 25 i 381 ustawy z dnia 19 marca 1928 r. - Kodeks postępowania karnego, tekst jednolity: Dz. U. z 1932 r. Nr 83, poz. 725.

32 Archiwum Państwowe w Lublinie 35/496/0/4/323. 
Jak można przeczytać $\mathrm{w}$ uzasadnieniu zawiadomieniu o popełnieniu przestępstwa, dnia 12 kwietnia 1932 r. Maria Wolska zawarła z nieżyjącym już mężem umowę sprzedaży nieruchomości w Lublinie, podając jej wartość na kwotę 4000 zł. Notariusz sporządzający akt notarialny pobrał tytułem opłaty stemplowej kwotę $160 \mathrm{zł}$, czyli $4 \%$ od wartości umowy i 10\% dodatek w wysokości 16 zł. Powołany w sprawie świadek - Kazimierz Barczewski, który dokonał oszacowania majątku po zmarłym Andrzeju Wolskim, stwierdził, że nieruchomość będąca przedmiotem umowy sprzedaży z dnia 12 kwietnia 1932 r. przedstawiała w dniu szacowania, tj. w 1937 r., wartość $104490 \mathrm{zł}$. W dniu zawarcia umowy wartość ta wynosiła $73143 \mathrm{zł}$.

Opierając się na powyższej wycenie, świadek w sprawie Artur Pawlicki, naczelnik Urzędu Opłat Stemplowych w Lublinie, stwierdził, że opłata stemplowa powinna wynieść 2925,70 zł, 10\% dodatku w kwocie 292,58 zł oraz dodatek komunalny w wysokości 1462,90 zł. Prokurator zakwestionował zatem wycenę sprzedawanej nieruchomości jako przyjętej za podstawę wymiaru opłaty stemplowej jako naruszającej art. 12 ustawy stemplowej.

W konkluzji aktu oskarżenia stwierdzono, że w związku z podaniem przez oskarżoną zaniżonej wartości przedmiotu umowy doszło do uszczuplenia Skarbu Państwa na kwotę 2765,70 zł z tytułu opłaty stemplowej oraz o kwotę 276,58 zł z tytułu 10\% dodatku. Oskarżona do winy się nie przyznała i stwierdziła, iż w dniu zawarcia transakcji podano cenę prawidłową, a wartość nieruchomości wzrosła dopiero na skutek prowadzonej później rozbudowy tej części miasta.

Zgodnie zatem $\mathrm{z}$ ustaleniami prokuratury doszło do świadomego zniżenia ceny sprzedawanej nieruchomości, od której należna była opłata stemplowa w wysokości $4 \%$ celem osiągnięcia z tego tytułu korzyści majątkowej w postaci zapłaty niższej opłaty stemplowej od przewidzianej prawem. Jak wynika z treści aktu oskarżenia, notariusz zastosował prawidłową stawkę przewidzianą $\mathrm{w}$ art. 58 ust. 1 ustawy stemplowej.

Sprawę z aktu oskarżenia rozpoznał Sąd Okręgowy w Lublinie z dnia 19 maja 1937 r. (sygn. I 1K 257/17), uznając oskarżoną za winną i skazał ją na karę pieniężną w wysokości 2765,80 zł, czyli w kwocie niepobranej opłaty, a w razie braku możliwości jej ściągnięcia na 3 miesiące aresztu, oraz obciążył skazaną kosztami procesu w wysokości 276,58 zł. Był to najniższy przewidziany prawem wymiar kary.

Jak wynika z uzasadnienia Sądu Okręgowego, podczas rozprawy oskarżona nie przyznała się do winy, broniąc się faktem, że nie była obecna podczas spisywania projektu umowy sprzedaży, a to mąż podał wartość nieruchomości, która miała być zapisem za zwrot posagu, jaki wniosła w związek małżeński. Sąd nie dał wiary zeznaniom strony i opierając się na zeznaniach świadków, ustalił, że oskarżona znała wartość sprzedawanej nieruchomości, a fakt, że projekt umowy spisano podczas 
jej nieobecności, nie może być usprawiedliwieniem, ostatecznie bowiem został jej odczytany i przez nią podpisany. Miała zatem wszelką sposobność, aby zakwestionować cenę nieruchomości, a tego nie zrobiła. Co więcej, w innym postepowaniu córka oskarżonej w maju 1936 r. wniosła przeciwko oskarżonej powództwo i uznanie aktu sprzedaży za pozorny, ukrywający darowiznę i szkodzącym jej prawom do spadku. To wszystko zdaniem sądu ponad wszelką wątpliwość potwierdzało, że oskarżona świadomie podała nieprawdziwą cenę nieruchomości ${ }^{33}$.

Pomimo niskiego wymiaru kary oskarżona odwołała się do wyroku, wnosząc o jego uchylenie $\mathrm{z}$ uwagi na brak znamion przestępstwa określonego $\mathrm{w}$ art. 40 ustawy stemplowej. Apelacja oparta została o zarzut, że „korzystne” nabycie nieruchomości nie może być przestępstwem. Przeciwna interpretacja sprowadzałaby się do faktu, że strony umowy przed zawarcie każdej umowy sprzedaży nieruchomości powinny przeprowadzić urzędową wycenę celem oszacowania wartości rzeczy sprzedawanych. Takie zobowiązanie nie istniało $\mathrm{w}$ chwili podpisywania umowy. W ocenie strony apelującej sąd pominął również okoliczność, że oskarżona faktycznie nie zapłaciła za nieruchomość, gdyż to mąż oskarżonej pragnąć zwrócić oskarżonej otrzymaną od niej ziemię, przeniósł na nią prawo własności nieruchomości, o której mowa w akcie oskarżenia. Oskarżona wskazała również, że przestępstwo określone w art. 40 ustawy stemplowej dotyczy sytuacji, kiedy to w umowie podaje się zaniżoną cenę, a faktycznie płaci wyższą od tej określonej w umowie, co nie miało miejsca w tej sprawie ${ }^{34}$.

Sąd Apelacyjny wyrokiem z dnia 6 listopada 1937 r. (sygn. KA 2793/37) utrzymał wyrok sądu I instancji, jednocześnie stwierdzając $z$ urzędu, że nie zachodzi przedawnienie czynu oskarżonego.

\section{Zakończenie}

Opisane w niniejszym artykule zdarzenia pociągały za sobą diametralnie odmienne skutki prawne. W sytuacji zakwestionowania przez władze skarbowe prawidłowości co do zastosowanej przez notariusza stawki opłaty stemplowej dla danego pisma podatnik miał praktycznie dwa wyjścia: zgodzić się z wymiarem opłaty stemplowej przedstawionej nakazem płatniczym lub wnieść stosowne odwołanie do Izby Skarbowej. Istotne jest to, że pomimo błędu notariusza to sam podatnik $\mathrm{w}$ toku procesu

33 Archiwum Państwowe w Lublinie 35/496/0/4/323.

34 Tamże. 
odwoławczego musiał de facto bronić stanowiska notariusza. Zaniżenie natomiast wartości transakcji, czyli świadome podanie notariuszowi stanu faktycznego niezgodnego z rzeczywistością, było już przestępstwem zagrożonym karą.

Pierwsze rozwiązanie było naturalną konsekwencją ustanowienia notariusza „organem urzędowym”. Istotne jest, że w przypadku wystawienia nakazu płatniczego podatnik nie ponosił kary z tytułu uiszczenia opłaty w niewłaściwej wysokości. Jeżeli zgadzał się z wymiarem opłaty przedstawionym w nakazie płatniczym lub Izba Skarbowa nie uwzględniła jego odwołania, miał obowiązek jedynie dopłacić opłatę stemplową do wysokości wynikającej z nakazu płatniczego. Faktycznych konsekwencji nie ponosił też sam notariusz, gdyż jako organ urzędowy powołany do wymierzenia i pobrania opłaty stemplowej nie podlegał karze pieniężnej w wysokości od 5 do 300 zł za naruszenia ustawy stemplowej. Zastosowanie błędnej stawki opłaty nie było bowiem uznawane za naruszenie ww. ustawy. Podlegał on oczywiście odpowiedzialności za niedopełnienie swego obowiązku na zasadach ogólnych, czyli odpowiedzialności odszkodowawczej ${ }^{35}$. Dodatkowo notariusz mógł ponieść odpowiedzialność dyscyplinarną za przewinienia służbowe, zagrożone karami dyscyplinarnymi w postaci upomnienia, nagany, grzywny do $10000 \mathrm{zł} \mathrm{lub}$ nawet pozbawienia stanowiska notariusza (art. 44 i 45 prawa o notarjacie). Jakkolwiek, jak czytamy na łamach „Przeglądu Notarjalnego” z 1938 r., notariusze pomimo braku takiego obowiązku ustawowego - odnosząc się do negatywnych konsekwencji, jakie dla podatnika pociągał ze sobą błąd notariusza - niejednokrotnie sporządzali odwołania od nakazów płatniczych, podważających zastosowaną przez nich stawkę do danego pisma. Proceder był powszechny i jawnie uprawiany przez notariuszy, czym według Izby Skarbowej uchybiali oni godności zawodu zaufania publicznego. Autor w konkluzji bronił jednak takich działań, stwierdzając, że jeżeli ta pomoc miała charakter bezinteresowny i mający na celu jedynie udzielenie pomocy prawnej przy opracowaniu odwołania, to nie była ona wyrazem uchybienia godności zawodu ${ }^{36}$.

Drugie zdarzenie było już uznawane za świadome działanie zmierzające do zaniżenia opłaty stemplowej, stanowiące czyn zabroniony w myśl art. 40 ustawy stemplowej. Tak jak podatnik nie miał wpływu na wysokość stawki opłaty stemplowej zastosowanej przez notariusza, tak na fakt wskazania prawidłowej (rynkowej) ceny sprzedaży już miał. Wobec stosunkowo wysokich stawek tej opłaty, szczególnie w przypadku pism stwierdzających sprzedaż nieruchomości, niewątpliwie kuszące było świadome zaniżenie ceny celem zapłacenia niższego podatku, tym

35 Zob. Przegląd Skarbowy 1937, z. 7-8, s. 378-379.

36 Współdziałanie notariusza w postępowaniu odwoławczym, Przegląd Notarjalny 1938, nr 10, s. 17. 
bardziej - jak wskazano - że notariusz nie posiadał instrumentów do zakwestionowania podanych przez strony wartości sprzedawanej nieruchomości. Świadome podanie stanu faktycznego niezgodnego z rzeczywistością było przestępstwem, które mogło być ujawnione dopiero w procesie nadzorczym. W tym kontekście, potwierdzało to fakt, że często dochodziło do świadomego podawania cen niezgodnych ze stanem rzeczywistym.

Słowem podsumowania przytoczyć należy dyskusję, która rozgorzała na łamach „Przeglądu Notarjalnego” z 1934 r. pomiędzy K. Żurowskim a A. Rosenkranzem w odniesieniu do tezy wyroku Najwyższego Trybunału Administracyjnego z dnia 6 maja $1930 \mathrm{r}^{37}$, na podstawie której ten pierwszy postawił wniosek de lege ferenda, nakładający na notariuszy obowiązek przedkładania właściwym urzędom skarbowym wszelkich aktów notarialnych przed nimi sporządzonych, w tym tych dotyczących ofert sprzedaży nieruchomości, co pozwoli wyeliminować wypadki celowego obejścia ustawy. Autor postulował zatem wprowadzenie obligatoryjnych rozwiązań przewidzianych już uprzednio w art. 29 ustawy stemplowej, eliminujących zarazem notariuszy z katalogu organów urzędowych. Autor przytacza tezę wyroku NTA, zgodnie z którą notariusz miał obowiązek należytego sporządzenia aktu i zbadania, czy składane oświadczenia nie sprzeciwiają się prawu. Ustalenie zaś charakteru dokumentu oraz zbadanie zamiaru stron było już kompetencją właściwej władzy skarbowej, a nie notariusza. Autor zaznaczył, iż wobec rewizji aktów przez władze skarbowe w odstępach kilkuletnich właściwe byłoby właśnie przekazywanie tych aktów władzy stemplowej celem sprawdzenia, czy nie doszło do świadomego zaniżenia ceny ${ }^{38}$.

Z postulatami tymi nie zgodził się A. Rosenkranz, wskazując po pierwsze, że nie przysługiwało zażalenie na odmowę sporządzenia aktu notarialnego przez notariusza, $\mathrm{z}$ uwagi na nieuiszczenie opłat państwowych w myśl $\$ 5$ art. 66 prawa o notarjacie, co według niego dawało notariuszowi prawo odnowy sporządzenia aktu, gdy ten zmierzał do obejścia ustawy stemplowej ${ }^{39}$. Tym samym, jeżeli notariusz powziąłby informację o świadomym zaniżeniu ceny, powinien odmówić sporządzenia takiej umowy. Jakkolwiek K. Żuromski bronił swojego stanowiska ${ }^{40}$, to jednak dyskusja ta pokazała, ile ewentualnych prób obejścia ustawy stemplowej mogłoby być rozstrzygnięte przez władze skarbowe w przypadku wprowadzenia obowiązku

37 L. Rej. 2609/28, zob. K. Żuromski, Oferta co do nieruchomości. Kilka uwag de lege ferenda, Przegląd Notarjalny 1934, nr 3, s. 63.

38 Tamże, s. 15.

39 A. Rosenkranz, Notariusz jako poborca..., s. 125.

40 K. Żuromski, Jeszcze o opłacie stemplowej przy ofertach co do nieruchomości w świetle wykładni N.T.A., Przegląd Notarjalny 1934, nr 9, s. 198-201. 
przekazywania wszystkich aktów dotyczących tak ofert sprzedaży, jak i sprzedaży nieruchomości. Rozwiązanie takie mogłoby zostać wprowadzone niezależnie od utrzymania mechanizmu wymiaru poboru i opłaty stemplowej przez notariusza.

Ostatecznie, tylko świadomość podatnika, iż każda umowa sprzedaży nieruchomości byłaby kontrolowana przez władze skarbowe w zakresie tego, czy cena sprzedawanej nieruchomości odpowiadała wymogom art. 12 ustawy stemplowej, pozwoliłaby uniknąć prób obchodzenia ustawy, jednocześnie umożliwiłoby to na szybkie sprawdzenie też wysokości opłaty pobranej przez notariusza. Jednak ustawodawca takiego rozwiązania nie przyjął, wierząc, że przyjęty mechanizm obdarzenia notariusza przymiotem „urzędnika skarbowego” pozwoli zaoszczędzić czas i pieniądze w zakresie obsługi poboru opłat stemplowych. Jednak wniosek z przeprowadzonej kwerendy archiwalnej i dyskusji pomiędzy K. Żurowskim a A. Rosenkranzem prowadzi wprost do konkluzji odmiennej od założeń ustawodawcy.

\section{Bibliografia}

Antonów D., Opata skarbowa w polskim porządku prawnym, Warszawa 2017.

Antonów D., Unifikacja opłat stemplowych $w$ okresie rządów sanacji - ustawa $z 1$ lipca 1926 roku o opłatach stemplowych, Studia Nad Autorytaryzmem i Totaliryzmem 2018, t. 40 , nr 4 .

Buczma-Czapliński M., Poradnik prawniczy, Lwów-Warszawa-Poznań 1932.

Cichowicz L., Anytomia pomiędzy art. 28 ust. 2 a art. 27 liczba 1 oraz art. 1, 5, 10 ustawy stemplowej, dalej ordynacja notarjacka $w$ ust. pr. o sadownictwie niepornem $z 21$ września 1899, Czasopismo Adwokatów Polskich 1927, nr 2.

Gliniecka J., Prawna ewolucja konstrukcji przedmiotu opłaty skarbowej w polskim systemie dochodów samorzadowych, Gdańskie Studia Prawnicze 2015, t. 34.

Jaworski W., Reforma rolna a hipoteka i kataster, Przegląd Notarjalny 1928, nr 2.

Jaworski W., Obrót ziemia w obecnym ustawodawstwie, Przegląd Notarjalny 1930, nr 1-2.

Kępa M., Ewolucja opodatkowania obrotu niezawodowego w Polsce w latach 1918-1947, Studia Iuridica Lublinensia 2010, t. 14.

Kodeks Stemplowy, Lwów 1927.

Kozioł F., Opłaty stemplowe, w: Odrodzona skarbowość polska, Warszawa 1931.

Markowski A., Podatki od obrotów i opłaty, Warszawa 1924.

Rosenkranz A., Zasady wytyczne projektu ustawy o opłatach stemplowych, Warszawa 1924.

Rosenkranz A., Noatarjusz jako poborca opłat stemplowych. Kilka założeń ogólnych w związku ze sprawa „Ofert co do nieruchomości”, Przegląd Notarjalny 1934, nr 6.

Stein S., Kilka uwag o zastosowaniu praktycznem nowej ustawy stemplowej, Przegląd Notarjalny 1927, nr 1.

W sprawie wykładni ustawy stemplowej, Przegląd Notarjalny 1927, nr 1. 
Współdziałanie notariusza w postępowaniu odwoławczym, „Przegląd Notarjalny” 1938, nr 10.

Zakrocki L., Na drogach i bezdrożach ustawy stemplowej, Przegląd Notarjalny 1928, nr 1-2. Żuromski K., Oferta co do nieruchomości. Kilka uwag de lege ferenda, Przegląd Notarjalny $1934, \mathrm{nr} 3$.

Żuromski K., Jeszcze o opłacie stemplowej przy ofertach co do nieruchomości w świetle wykładni N.T.A., Przegląd Notarjalny 1934, nr 9. 
